\title{
Fire and explosion risk assessment in a chemical company by the application of DOW fire and explosion index
}

\author{
Zarranejad A, $\mathrm{PhD}^{1}$, Ahmadi O, $\mathrm{MSc}^{2 *}$ \\ 1- PhD in Occupational Health Engineering, Dept of. Sciences of Occupational Health, Tarbiat Modares University, Tehran, \\ Iran. 2- MSc in Occupational Health Engineering, Dept. of Sciences of Occupational Health, Tarbiat Modares University, \\ Tehran, Iran.
}

\begin{abstract}
Received: April 2016, Accepted: July 2016

Background: Fire and explosion hazards are extremely important in processing units. This study was performed to identify the risk centers, the potential damage caused by fire and explosion, and the days of production cessation in the processing company.

Materials and Methods: The present qualitative case study was conducted using Dow's index in 2015. The fire and explosion hazard index and level were calculated for the processing units after collecting the required data. In addition, hazard radius and level, damage factor (DF), actual maximum probable property damage (MPPD), and the maximum probable days' outage (MPDO) were determined by analysis of the collected data.

Results: The results indicated that the fire and explosion hazard level was high in $82 \%$ of the studied processing units. Moreover, the potential fire or explosion could cause financial damage of 51 million dollars and production cessation of 296 days.

Conclusions: The results of this study showed a variety of possible fire and explosion hazards in the studied processing units. By determining several weakness points in these units, serious engineering controls were suggested to decrease the determined hazard levels. Furthermore, Dow's fire and explosion index (F\&EI) was approved as an efficient technique for assessing the risk of fire or explosion in addition to their damage levels.
\end{abstract}

Keywords: Explosion, Fire, Chemical, Index.

\section{Introduction}

Chemical and processing units are at risk of fire and explosion due to a variety of reasons including fire hazards, chemical reactivity, and leakage of materials. Catastrophic events, production cessation, and damage to the equipment and organizational investments may occur due to the lack of accurate recognition and assessment of these hazards. The accidents that occurred in the Flixborough chemical complex (England), Pasadena chemical complex (USA), Mexico City LPG Terminal, Feyzin Refinery (France), and Piper Alpha Oil Production Platform can be given as examples of these catastrophic events. Therefore, the mentioned hazards should be identified, assessed, and controlled to ensure the security of the processing industries (1).
Towards this goal, the processes of recognition and risk assessment of fire and explosion hazards have been performed through different methods. The occurrence of various accidents induced by fire and explosion hazards indicates that the classical techniques of risk assessment are not effective enough due to the unspecialized point of view to the risk assessment processes. Thus, accurate and dexterous methods are required to identify and assess fire and explosion risks from a specialized viewpoint. Dow's Fire and Explosion Index (F\&EI) has been recently developed to identify and investigate fire and explosion hazards. This index (which does not

\footnotetext{
* Corresponding author: Omran Ahmadi, Dept. of Sciences of Occupational Health, Tarbiat Modares University, Tehran, Iran.

Email: O.ahmadi@modares.ac.ir
} 
require high levels of specialty and details) calculates the general risks of processing units through a simple and comprehensive method. This method is based on historical loss data, the energy potential of materials, and the extent to which loss prevention practices are currently applied. Dow uses numerical values of hazard factors associated with different material and process characteristics to determine fire and explosion hazards in a stepby-step objective evaluation. Therefore, incorporation of such a method (especially for recognizing the critical points) is indispensable due to its key advantages including economic identification, saving time and concentration on the fire and explosion control activities in important and critical sections. In addition to the investigation and quantification of total effective parameters in fire and explosion occurrence, Dow's index can efficiently assess other useful information such as the maximum amount of potential damage, maximum days of production cessation in probable explosion and fire $(2,3)$. The main aim of this method was not to classify the facilities into safe and unsafe categories; however, a relative ranking of hazards and risks in an organization can be provided (4).

The F\&EI was designed by Dow and the American Institute of Chemical Engineers (AIChE) in 1967. This method has since been revised six times. Its last revision ( $7^{\text {th }}$ edition) was published by Suardin (5). Etowa et al. developed a computer program based on this method to automate F\&EI calculation (6). Different researches have been conducted on the incorporation of this method in different applications. Etowa et al. employed this method to investigate the inherent safety of reservoirs used for storing methyl isocyanate(6). Rigas et al. performed a comprehensive study for the safety analysis of a new production line in a pesticide factory in Northern Italy using Dow's method(7) In this regard, Suardin (5) and Hendershot(8) can also be studied.

Moreover, Ahmadi et al. conducted a study for the rational ranking of fire and explosion hazards in a petrochemical industry (9). The quantitative determination of fire and explosion risk in a processing unit was also performed by Ahmadi et al. (10).

The main aims of the present study were to identify fire and explosion hazards and assess the induced risk in a processing company. Other goals of the study were to predict the maximum probable damage and determine the maximum number of days of production cessation using Dow's F\&EI, and to present appropriate control guidelines.

\section{Material and Methods}

The present qualitative case study was performed on a processing company (in Southern Iran) in 2015 using Dow's F\&EI. Dow's index was first introduced in 1964 by a chemical materials production company named Dow. It has since then been revised 6 times and the last version was presented in 1994. Dow's F\&EI (as one of the specific and useful methods for risk assessment and evaluation of the damage induced by fire and explosion in processing industries) has provided an appropriate framework for identification and assessment of fire and explosion damages. It has also provided effective ways for controlling of the identified hazards. This method calculates the risks of fire and explosion hazard in processing units in a simple, fast, and comprehensive way. Moreover, it does not require high level of specialty and process details $(11,12)$.

The implementation process of the present study is defined in the following stages.

Preliminary data collection: In the first stage, the required information were obtained for coordinates of units' installation and location, equipment, and the main piping routes and cables by investigation of the plot plan. In addition, the required information on the schematic view of the studied system, the flow between the principal system elements, and the basic design, such as quantity and quality of the utilized materials in the processes, were collected by investigating the 
process flow diagrams (PFDs). The required detailed information on the relationship between the parts, machines, valves, fittings, and other mechanical parts were determined using piping and instrumentation diagrams/drawings (P\&IDs) (3).

Processing units: After the preliminary data collection and familiarization with the processes, the studied company was classified into processing units. In this study, the processing unit was defined as an element from the processing equipment that could be investigated as an independent system such as reactor, distillation column, absorption tower, compressor, pump, furnace, and reservoir. Any identified processing unit was then accurately investigated in terms of stock materials, the materials' potential chemical energy, operational conditions, records of past damages, and its potential ability to stop the production. The effects of the mentioned parameters were investigated on the whole process regarding fire and explosion to select those processing units that had severe adverse effects on the process $(2,3)$.

Material factor (MF): In this stage, the quantitative and qualitative characteristics of the chemicals were determined, and based on that, the material factors were calculated for each processing unit. Material factor can be defined as the material's emission intensity and release of potential energy which may be calculated by considering its flammability and reactivity. The material factor usually ranges from 1 to 40 and can be determined based on standards NFPA-325M and NFPA-49 considering material flammability (NF) and reactivity (NR).

The calculated parameter is the base factor representing the hazard level at surrounding environment's temperature and pressure conditions. The material factors were revised because the environmental conditions differed from the processing conditions in the studied units. Since, several materials were usually used in each processing unit, the maximum values between the calculated material factors were considered according to the weight percentage of the material $(3,11)$.

Process general hazards factor: In this stage, the process's general hazards (which are generally classified into 6 main categories) were identified. Since existence of these hazards in processing units could induce the risk of fire and explosion, a specific penalty value was assigned for each of the identified hazards according to table 1. Clearly, the higher levels of hazards induced received higher penalty. Furthermore, the penalty value was ignored if there was no hazard. Finally, the total values of the assigned penalties were calculated for the identified hazards and process general hazards factor $\left(\mathrm{F}_{1}\right)$ was obtained for the processing units by addition of 1 to its value $(2,3)$.

Table 1: General process hazards and corresponding penalties

\begin{tabular}{|c|c|c|}
\hline $\begin{array}{c}\text { General process } \\
\text { hazards (F } F_{1} \text { or GPHs) }\end{array}$ & Description & $\begin{array}{c}\text { Penalty } \\
\text { value }\end{array}$ \\
\hline \multirow{4}{*}{$\begin{array}{c}\text { Exothermic chemical } \\
\text { processes }\end{array}$} & $\begin{array}{l}\text { Mild reactions such as hydrogenation, hydrolysis, isomerization, } \\
\text { sulfating, and neutralization }\end{array}$ & 0.30 \\
\hline & $\begin{array}{l}\text { Moderate reactions such as alkylation, esterification, oxidation, } \\
\text { polymerization, condensation, and incremental reactions }\end{array}$ & 0.50 \\
\hline & $\begin{array}{l}\text { Severe reactions within which the control of reaction conditions } \\
\text { was difficult and critical such as halogenation }\end{array}$ & 1.00 \\
\hline & Sensitive exothermic chemical processes such as nitration & 1.25 \\
\hline \multirow[b]{2}{*}{$\begin{array}{c}\text { Endothermic } \\
\text { chemical processes }\end{array}$} & Endothermic chemical reactions that occurred in the reactor & 0.20 \\
\hline & $\begin{array}{l}\text { Endothermic chemical reactions that occurred in the reactors and } \\
\text { their energy sources were provided from combustion of solid, } \\
\text { liquid, and gas fuels such as lime production (calcination) and } \\
\text { materials pyrolysis induced by direct contact with fire }\end{array}$ & 0.40 \\
\hline $\begin{array}{l}\text { Manual handling, } \\
\text { transportation and }\end{array}$ & $\begin{array}{l}\text { Performance of loading and unloading of grade one flammable } \\
\text { liquids and liquid pressurized gases (LPG) in one way in a }\end{array}$ & 0.50 \\
\hline
\end{tabular}




\begin{tabular}{|c|c|c|}
\hline \multirow[t]{8}{*}{ material warehousing } & \multicolumn{2}{|l|}{ continuous or discontinuous way } \\
\hline & $\begin{array}{l}\text { Those processes within which the detonative mixes may appear } \\
\text { during material addition (induced by contact with air) or other } \\
\text { reactivity hazards may be revealed such as centrifuge, } \\
\text { discontinuous or interrupted reactions, and modular mixing. }\end{array}$ & 0.50 \\
\hline & \multicolumn{2}{|c|}{$\begin{array}{l}\text { The following penalties have been applied according to the materials in cases in } \\
\text { which they were stored in roofed warehouses or outdoor environment (unroofed } \\
\text { warehouses). }\end{array}$} \\
\hline & Flammable gases or liquids with NF $=3$ or 4 & 0.85 \\
\hline & Volatile solids with $\mathrm{NF}=3$ & 0.65 \\
\hline & Volatile solids with $\mathrm{NF}=2$ & 0.40 \\
\hline & Flammable liquids with $140^{\circ} \mathrm{F} / 60^{\circ} \mathrm{C}<\mathrm{FP}_{\text {closed cup }}>100^{\circ} \mathrm{F} / 37.8^{\circ} \mathrm{C}$ & 0.65 \\
\hline & $\begin{array}{l}\text { Note: The penalty value was increased by } 0.2 \text { if the mentioned ma } \\
\text { stored in racks lacking rack sprinkler. }\end{array}$ & ls were \\
\hline \multirow{6}{*}{$\begin{array}{l}\text { Enclosed/closed or } \\
\text { internal processing } \\
\text { units }\end{array}$} & In cases in which the filters or dust collectors were in a closed area & 0.50 \\
\hline & $\begin{array}{l}\text { Processes within which flammable liquids were incorporated in } \\
\text { temperatures higher than their flash points }\end{array}$ & 0.30 \\
\hline & $\begin{array}{l}\text { In cases in which the flammable liquid mass was higher than } 10 \\
\text { Mlb }\end{array}$ & 0.45 \\
\hline & $\begin{array}{l}\text { Processes within which LPG or flammable liquids were } \\
\text { incorporated in temperatures higher than their boiling point }\end{array}$ & 0.60 \\
\hline & $\begin{array}{l}\text { In cases in which the liquid weight was more than } 10000 \mathrm{lb} \text { (equal } \\
\text { to } 1000 \text { American gallons) }\end{array}$ & 0.90 \\
\hline & $\begin{array}{l}\text { Note: The penalty values were decreased up to } 50 \% \text { if appropriat } \\
\text { systems were installed for the above mentioned cases }\end{array}$ & tilation \\
\hline \multirow{2}{*}{ Accessibility } & $\begin{array}{l}\text { In cases of inappropriate accessibility to the processing regions } \\
\text { with area of more than } 10000 \mathrm{ft}^{2}\left(925 \mathrm{~m}^{2}\right)\end{array}$ & 0.35 \\
\hline & $\begin{array}{l}\text { In case of inappropriate accessibility to the warehouses with area } \\
\text { of more than } 25000 \mathrm{ft}^{2}\left(2312 \mathrm{~m}^{2}\right)\end{array}$ & 0.35 \\
\hline \multirow{5}{*}{$\begin{array}{l}\text { Drainage and leakage } \\
\text { control }\end{array}$} & \multicolumn{2}{|c|}{$\begin{array}{l}\text { In processes within which flammable materials were incorporated in flash points } \\
\text { of above } 140^{\circ} \mathrm{F} \text { or for materials that were employed in process condition above } \\
\text { their flash point if }\end{array}$} \\
\hline & $\begin{array}{l}\text { Barrier walls existed which surrounded the equipment capable of } \\
\text { causing fire }\end{array}$ & 0.50 \\
\hline & $\begin{array}{l}\text { A flat area existed near the processing unit which facilitated the } \\
\text { materials leakage development and exposed the region to high risk } \\
\text { of fire }\end{array}$ & 0.50 \\
\hline & $\begin{array}{l}\text { Barrier walls existed that surrounded the processing unit from } \\
\text { three sides which guided the leaked materials to a discharge pool } \\
\text { or covered drainage canal }\end{array}$ & 0.00 \\
\hline & $\begin{array}{l}\text { Pools or discharge canals in a processing unit passing telephone } \\
\text { and electricity lines specified regions or the safe distances from } \\
\text { these lines were not considered in processing unit design }\end{array}$ & 0.50 \\
\hline
\end{tabular}

Process-specific hazards factor: The processspecific hazards factor $\left(\mathrm{F}_{2}\right)$ (that is classified into 12 main categories) was identified in this stage. A certain penalty value was considered for any identified hazards according to the manual indicated in table 2 by considering the risk of fire and explosion that may be caused by these hazards. The penalty value was increased for higher levels of process-specific hazards. Finally, the total penalties assigned to the identified process-specific hazards were calculated, and by addition of +1 to its value, factor $F_{2}$ was obtained for processing units (2, $3)$.

Processing unit hazards factor: The hazards factor of the processing units $\left(\mathrm{F}_{3}\right)$ was calculated using the following equation (3):

$$
F_{3}=F_{1} \times F_{2}(1)
$$


Table 2: Specific process hazards and corresponding penalties

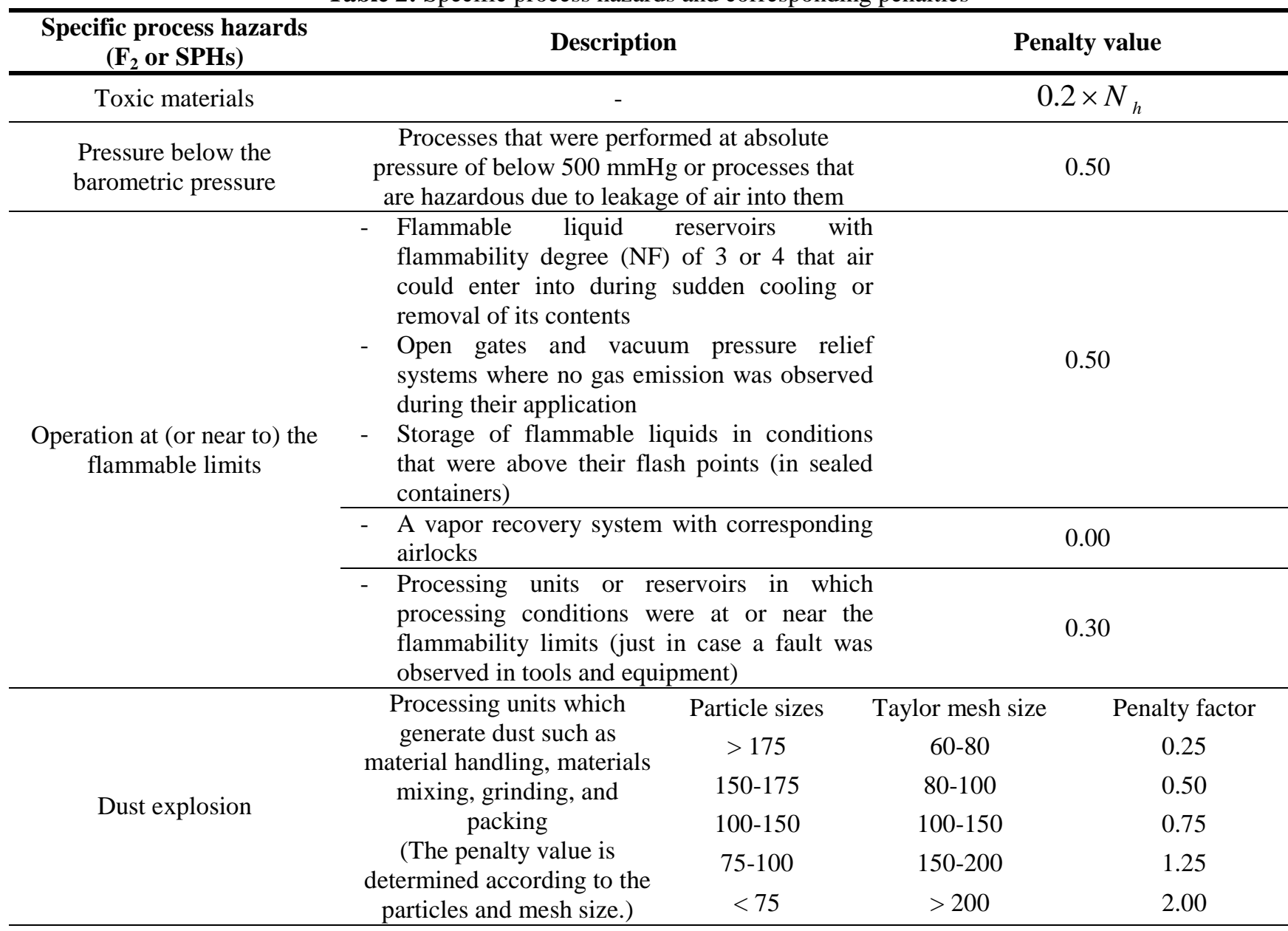

In processing units which were working above the barometric pressure, the penalty value was determined based on the operational pressure.

For pressure limit of 1000 psig, the penalty value was determined using the following equation:

Relief pressure

$$
Y=0.16109+1.61503\left(\frac{X}{1000}\right)-1.42879\left(\frac{X}{1000}\right)^{2}+0.5172\left(\frac{X}{1000}\right)^{3}
$$

\begin{tabular}{ccc}
\hline & Pressure (psig) & Penalty value \\
For pressure of & 1000 & 0.86 \\
more than $1000 \mathrm{psig}$ & 1500 & 0.92 \\
& 2000 & 0.96 \\
& 2500 & 0.98 \\
& $3000-1000$ & 1.00 \\
& $>10000$ & 1.50
\end{tabular}

In processes within which the temperature may decrease to lower than transition point because of normal or abnormal operational conditions.

Low temperature

- Hard steel was used or the operational

conditions were at or below the transition

temperature (soft a.nd flexible/brittle and fragile)

- Materials other than steel were used or the

operational conditions was at or below the transition temperature

Flammable and unstable materials
The first category (the liquids and gases existing in the process) which consist of

flammable liquids with flash points below $140^{\circ} \mathrm{F}$

$\left(60^{\circ} \mathrm{C}\right)$ and flammable gases, flammable liquid gases, and flammable liquids with flash points
Having the potential heat transfer value (in BTU)

the penalty factor was determined using the following equation:

$\log _{10} Y=0.17179+0.42988 \log _{10} X-0.37244(10$ 
The second category (liquids and gases stored in the reservoir) which were located outside the processing region consisted of

1. Liquid gases

2. Class I flammable liquids (with flash points $\quad \log _{10} Y=0.17179+0.42988 \log _{10} X-0.37244\left(\log _{11}\right.$ below $\left.100^{\circ} \mathrm{F} / 37.8^{\circ} \mathrm{C}\right) \quad \log Y=-0.403115+0.378703 \log _{10} X-0.046402$

3. Class II flammable liquids $\left(100^{\circ} \mathrm{F} / 37.8^{\circ} \mathrm{C}<\mathrm{FP} \quad \log Y=-0.558394+0.363321 \log _{10} X\right.$ $<140{ }^{\circ} \mathrm{F} / 60^{\circ} \mathrm{C}$ )

The third category contained volatile solids in the inventory or the dust created in the process. The considered penalty value depends on the amount of materials in the inventory.

\begin{tabular}{ll}
\hline 1. Materials with a density above $10 \frac{l b}{f^{3}}$ & $\log _{10} Y=-0.358311+0.459926 \operatorname{lo}_{1}$ \\
\hline 1. Materials with a density below $10 \frac{l b}{f^{3}}$ & $\log _{10} Y=0.280423+0.4645$
\end{tabular}

The amount of corrosion was defined as the summation of the internal and external corrosion degrees

\begin{tabular}{cc}
\hline Corrosion below 0.5 in/year $(0.127 \mathrm{~mm} /$ year $)$ & 0.10 \\
\hline $\begin{array}{c}\text { Corrosion above } 0.5 \mathrm{in} / \text { year }(0.127 \mathrm{~mm} / \text { year }) \text { and } \\
\text { below } 1 \mathrm{~mm} / \text { year }\end{array}$ & 0.20 \\
\hline Corrosion above 1 in/year $(0.254 \mathrm{~mm} /$ year $)$ & 0.2 \\
\hline $\begin{array}{c}\text { The risk of cracking existed due to the corrosion } \\
\text { stress }\end{array}$ & 0.75 \\
\hline $\begin{array}{c}\text { Special coatings were used for prevention of } \\
\text { corrosion }\end{array}$ & 0.20
\end{tabular}

Processing units that incorporate materials with natural penetration capability or abrasive watery solutions which cause various problems in equipment sealing. Processes that used detachable seals

Leakage induced by fittings and sealing washers
Processing units with optical glass and expansion joints 1.50

\begin{tabular}{|c|c|}
\hline joints & 1.50 \\
\hline Pumps and seals with slight leakage & 0.10 \\
\hline $\begin{array}{l}\text { Pumps, compressors and flange fittings with } \\
\text { continuous leakage }\end{array}$ & 0.30 \\
\hline processes with pressurized and thermal cycles & 0.10 \\
\hline
\end{tabular}

Processing units which are placed near heaters with flame or themselves have flamed heaters

The considered penalty values depend on the distance between the heater and the potential leakage point (in $\mathrm{ft}$ ) which may be calculated using following equations: Processing units with potential emission of materials employed above their flash point Processing units within which flammable dust is

$$
\begin{aligned}
& \log _{10} Y=-3.3243\left(\frac{X}{210}\right)+3.751 \\
& \log _{10} Y=-3.745\left(\frac{X}{210}\right)-2.70212
\end{aligned}
$$
(burning equipment) incorporated

Processing units within which the probability of emission of materials above their boiling points exists

Hot oil heat exchangers were assessed as an independent process.

The utilized hot oil is not flammable or is utilized below its flash point

Hot oil heat exchangers

\begin{tabular}{cccc}
\hline $\begin{array}{c}\text { The penalty value for processing units using hot } \\
\text { oil heat exchangers or flammable hot oil }\end{array}$ & \multicolumn{2}{c}{ Penalty value } \\
\hline & Volu & Oils used above & Oils used \\
Amount of oil (American gallon) & me & flash point & $\begin{array}{c}\text { above boiling } \\
\text { point }\end{array}$
\end{tabular}




\begin{tabular}{|c|c|c|c|c|}
\hline & $<500$ & $\begin{array}{c}< \\
18.9\end{array}$ & 0.15 & 0.25 \\
\hline & $500-1000$ & $\begin{array}{l}18.9- \\
37.9\end{array}$ & 0.30 & 0.45 \\
\hline & $1000-2500$ & $\begin{array}{l}37.9- \\
94.6\end{array}$ & 0.50 & 0.75 \\
\hline & $>2500$ & $\begin{array}{c}> \\
94.6 \\
\end{array}$ & 0.75 & 1.15 \\
\hline & \multicolumn{2}{|c|}{$\begin{array}{l}\text { The existence of a flamed hot oil heat exchanger } \\
\text { in the processing unit }\end{array}$} & \multicolumn{2}{|c|}{$\begin{array}{l}\text { The penalty value was determined } \\
\text { according to the previous section of } \\
\text { the table. }\end{array}$} \\
\hline Rotating equipment & \multicolumn{2}{|c|}{$\begin{array}{l}\text { Processing units including one of the following } \\
\text { equipment: } \\
\text { - Compressor with power above } 600 \mathrm{hp} \\
\text { - Pumps with power above } 75 \mathrm{hp} \\
\text { - Mixers or rotating pumps with ability of creating } \\
\text { exothermic reactions in case some defects } \\
\text { occurred } \\
\text { - Large rotating equipment with high rotational } \\
\text { velocity such as centrifuges with history of } \\
\text { significant defects }\end{array}$} & \multicolumn{2}{|c|}{ ( } \\
\hline
\end{tabular}

Dow's fire and explosion index: Dow's fire and explosion index was calculated for each processing unit using the following equation (3):

$$
E I+F_{3} \times M F
$$

Fire and explosion hazards level: In this stage, the level of fire and explosion hazards was determined for each processing unit according to table 3 after calculation of Dow's index (3).

Exposure radius and area of exposure: Using Dow's index, the exposure radius (ER) and area of exposure (AOE) were calculated with the following equations (3):

$$
\begin{gathered}
E R=0.84 \times F \& E I(f t) \\
A O E=\pi \times E R^{2}(3)
\end{gathered}
$$

Table 3: Determination of fire and explosion hazards level

\begin{tabular}{lc}
\hline $\begin{array}{l}\text { Hazards level assessment } \\
\text { (According to the } \mathbf{5 - 7}^{\text {th }} \text { revisions) }\end{array}$ & Dow's F\&EI index limit \\
\hline Low/slight & $1-50$ \\
Limited & $51-81$ \\
Average & $82-107$ \\
High/heavy & $108-133$ \\
Severe & $\geq 134$ \\
\hline
\end{tabular}

Value of area exposed: The value of area exposed (VAE) was calculated (in million dollars) in two forms of original value (OV) and replacement value (RV) for each processing unit. The original value (OV) could be determined through the multiplication of the AOE by principal original cost density (OCD) as presented in the following equation (3):

$$
O V=A O E \times O C D
$$

The principal original cost density (OCD) was calculated by dividing the investment value by the total production elements values. The investment value can be defined as the monetary values of the physical investments in the studied case unit, such as equipment, machines, tools, structures, and buildings. The total values of the production elements can also be defined as the monetary values of all elements effective on production. This parameter can be calculated for the studied processing unit by addition of investment 
value to the costs related to the labor force, consumed material, energy, and etc.

The replacement value (RV) was also calculated using the following equation (3):

$$
R V=0.82 \times O V \times E F(5)
$$

Where EF is the escalation factor that is equal to inflation (in the year in which the research was conducted) summed by 1 . In the present study, the inflation was considered as $15 \%$.

Damage Factor: The damage factor (DF) was obtained for each processing unit by consideration of figure 1 , the material factor, and $F_{3}$ parameter $(2,3,12)$.

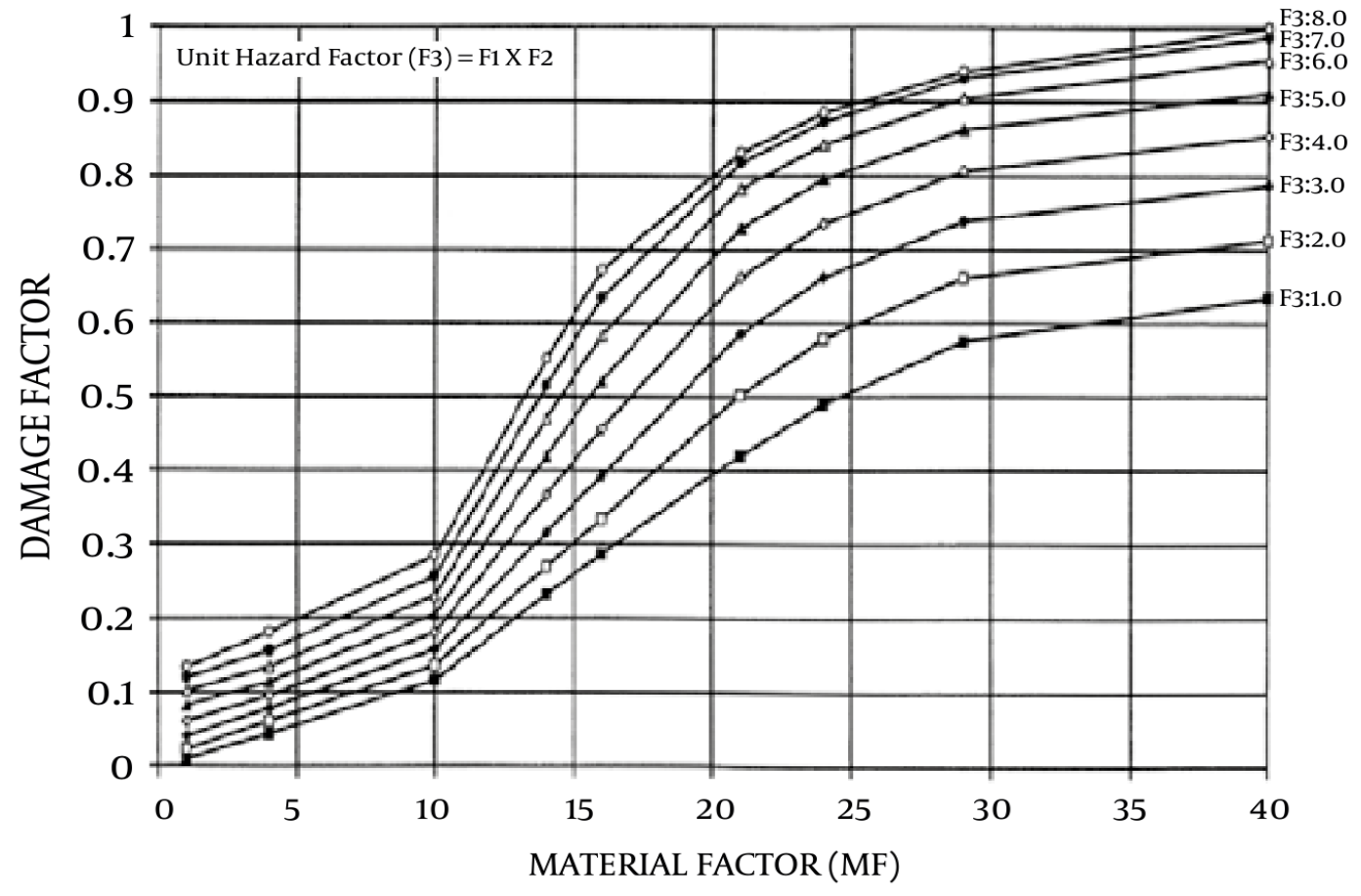

Figure 1: Determination of the hazard factor

Maximum Probable Property Damage: The value of the maximum probable property damage (MPPD) was calculated for each processing unit by multiplication of the value of area exposed by damage factor as presented in the following equation (3):

\section{Base $M P P D=V A E \times D F(6)$}

Credit Factor: The damage control credit factor (CF) was calculated with the following equation:

$$
C F=C_{1} \times C_{2} \times C_{3}
$$

Table 4: Determination of the process control factor

\begin{tabular}{ccc}
\hline Row & Description & Process control factor $\left(C_{l}\right)$ \\
\hline $\mathrm{a}$ & Existence of emergency electricity & 0.98 \\
\hline $\mathrm{b}$ & Existence of cooling systems & $0.97-0.99$ \\
\hline $\mathrm{c}$ & Existence of explosion control systems & $0.84-0.98$ \\
\hline $\mathrm{d}$ & Existence of emergency stop systems & $0.96-0.99$ \\
\hline $\mathrm{e}$ & Existence of computer control & $0.93-0.99$ \\
\hline $\mathrm{f}$ & Incorporation of noble gases in the process & $0.94-0.96$ \\
\hline $\mathrm{g}$ & Existence of operational manuals & $0.91-0.99$ \\
\hline $\mathrm{h}$ & Investigation of chemical reactions & $0.91-0.98$ \\
\hline $\mathrm{i}$ & Analysis of process hazards & $0.91-0.98$
\end{tabular}


Table 5: Determination of the material separation factor

\begin{tabular}{ccc}
\hline Row & Description & Materials separation factor $\left(C_{2}\right)$ \\
\hline $\mathrm{a}$ & Remote control valves & $0.96-0.98$ \\
\hline $\mathrm{b}$ & Waste discharge/pressurized discharge & $0.96-0.98$ \\
\hline $\mathrm{c}$ & Drainage & $0.91-0.97$ \\
\hline $\mathrm{d}$ & Automatic locks & 0.98 \\
\hline
\end{tabular}

Where $\mathrm{C}_{1}$ is the process control factor, $\mathrm{C}_{2}$ is the material separation factor, and $\mathrm{C}_{3}$ is the fire protection factor and its value was determined according to tables 4,5 , and 6 . Each of the factors of $\mathrm{C}_{1}$ to $\mathrm{C}_{3}$ consists of a set of safety and control measures. The process control factor $\left(\mathrm{C}_{1}\right)$ is defined as the parameter that reduces the probability and the risk intensity of the probable fire and explosion in a processing unit. Materials separation factor reduces the probability and the risk intensity of the probable material fire and explosion. In addition, the fire protection factor $\left(\mathrm{C}_{3}\right)$ reduces the probability and risk intensity of probable fire and explosion through reactive and preventive control actions. In this stage, the effectiveness of each mentioned control and safety action was accurately investigated on reducing the fire and explosion intensity and probability levels. Specific values were then assigned to each of these factors according to their limitations. It is noteworthy that no value would be assigned to the corresponding factor if none of the mentioned control and safety measures existed in the factors, or despite their existence, they were not effective enough to control the losses. After determination of the control and safety measures, their multiplication was used as the credit factor (3).

Actual maximum probable property damage: The actual maximum probable property damage (MPPD) (the most probable actual damage) was determined for each processing unit using the following equation (3):

$$
\text { Actual MPPD }=\mathrm{CF} \times \text { base MPPD }
$$

Maximum probable days outage factor: The factor of maximum probable days outage (MPDO) was determined by considering the MPPD and confidence level of below $70 \%$ using the following equation:

$$
\log _{10}=1.045515+0.610426 \times \log _{10} \mathrm{X}
$$

where, $\mathrm{X}$ is the actual MPPD factor (3).

Business interruption loss factor: The business interruption (BI) loss factor was determined (in million dollars) for each processing unit using the following equation:

$$
B I=0.7 \times \mathrm{MPDO} / 30 \times \mathrm{VPM}
$$

Where, VPM is the monthly production value in million dollars $(2,3,12-14)$.

Table 6: Determination of the fire protection and prevention factor

\begin{tabular}{ccc}
\hline Row & Description & Fire protection and prevention factor $\left(\boldsymbol{C}_{3}\right)$ \\
\hline $\mathrm{a}$ & $\begin{array}{c}\text { Existence of leakage identification } \\
\text { system }\end{array}$ & $0.94-0.98$ \\
\hline $\mathrm{b}$ & Existence of steel structures & $0.95-0.98$ \\
\hline $\mathrm{c}$ & $\begin{array}{c}\text { Existence of water resources for } \\
\text { extinguishing a fire }\end{array}$ & $0.94-0.97$ \\
\hline $\mathrm{d}$ & Existence of special systems & 0.91 \\
\hline $\mathrm{e}$ & Existence of sprinklers & $0.74-0.97$ \\
\hline $\mathrm{f}$ & Existence of water curtains & $0.97-0.98$ \\
\hline $\mathrm{g}$ & Existence of fire extinguishing suds & $0.92-0.97$ \\
\hline $\mathrm{h}$ & Existence of handy fire extinguishers & $0.93-0.98$ \\
\hline $\mathrm{i}$ & Existence of shields for cables & $0.94-0.98$ \\
\hline
\end{tabular}


Table 7: Processing units with their materials and material factors

\begin{tabular}{ccccc}
\hline No. & Processing unit & Material/main materials & $\begin{array}{c}\text { Material } \\
\text { factor }\end{array}$ & $\begin{array}{c}\text { Replaced material } \\
\text { factor }\end{array}$ \\
\hline 1 & Reactor R-A & Hydrogen, butane, ethane, and methane & 21 & 21 \\
2 & Reactor R-B & Hydrogen, methane, and heptane & 21 & 21 \\
3 & Reactor R-C & Hydrogen, propane, and propylene & 21 & 21 \\
4 & Tower DC & Benzene, toluene, and xylene & 16 & 21 \\
5 & Tower $\mathrm{DC}_{2}$ & Ethylene dichloride & 16 & 21 \\
6 & Tower $\mathrm{DC}_{3}$ & Diethyl ether & 21 & 21 \\
7 & Tower AC & Naphtha & 16 & 21 \\
8 & Tower $\mathrm{AC}_{3}$ & Methyl ethyl ketone & 16 & 16 \\
9 & Furnace $\mathrm{F}_{3}$ & Diesel fuel & 10 & 16 \\
10 & Reservoir $\mathrm{ST}_{1}$ & Naphtha & 16 & 21 \\
11 & Reservoir $\mathrm{ST}_{2}$ & Hydrogen & 21 & 21 \\
\hline
\end{tabular}

\section{Results}

In total, 11 processing units that had adverse effects on the whole process were chosen to be studied including reactors (R-A, R-B, and R$\mathrm{C})$, towers $\left(\mathrm{DC}_{1}, \mathrm{DC}_{2}, \mathrm{DC}_{3}, \mathrm{AC}_{3}\right.$, and $\left.\mathrm{AC} 3\right)$, furnace $\left(\mathrm{F}_{3}\right)$, and reservoirs $\left(\mathrm{ST}_{1}\right.$ and $\left.\mathrm{ST}_{2}\right)$. The initial and revised materials factors were obtained after determination of quantitative and qualitative properties of the chemical materials for each processing unit (Table 7). The highest material factor was obtained for Reactor R-A, Reactor R-B, Reactor R-C, Tower $\mathrm{DC}_{3}$, and Reservoir $\mathrm{ST}_{2}$ (equal to 21), and lowest material factor was obtained for Furnace $\mathrm{F}_{3}$ (equal to 10).

Furthermore, the general and special process hazards (GPHs and SPHs) were identified at each processing unit and are provided in table 8. Reactor R-B and Reactor R-C, respectively, with 2.20 and 2.10, and Reactor R-A with 1.25 had the highest and the lowest GPH factors, respectively. The SPH factor $\left(\mathrm{F}_{1}\right)$ was calculated for each identified hazard according to the existing manuals and Tower $\mathrm{DC}_{3}$ and Reservoir $\mathrm{ST}_{2}$ had the highest (6.80) and lowest values (4.20), respectively (Table 8). $\mathrm{F}_{3}$ (or PUHF) was determined for each processing unit and Reactor R-C (14.60) and Reservoir $\mathrm{ST}_{2}$ (6.30) had the highest and the lowest values, respectively (Table 8 ).

Dow's F\&EI and the fire and explosion hazards level are illustrated in table 8 . According to the results, Reactor R-C (306.6) and Reservoir $\mathrm{ST}_{1}$ (120) had the maximum and minimum fire and explosion indices, respectively. Fire and explosion hazards level was severe for all units except reservoirs $\mathrm{ST}_{1}$ and $\mathrm{ST}_{2}$; the hazards levels for these two units were high.

Table 8: Fire and explosion index and hazards level

\begin{tabular}{cccccc}
\hline & $\begin{array}{c}\text { General } \\
\text { Process } \\
\text { Hazards Factor }\end{array}$ & $\begin{array}{c}\text { Special Process } \\
\text { Hazards Factor }\end{array}$ & $\begin{array}{c}\text { Processing } \\
\text { Unit Hazards } \\
\text { Factor }\end{array}$ & $\begin{array}{c}\text { Dow's fire and } \\
\text { explosion index }\end{array}$ & $\begin{array}{c}\text { Fire and } \\
\text { explosion } \\
\text { hazards level }\end{array}$ \\
\hline Reactor R-A & 1.25 & 6.75 & 8.43 & 177.03 & Severe \\
Reactor R-B & 2.20 & 5.50 & 12.10 & 254.10 & Severe \\
Reactor R-C & 2.10 & 6.95 & 14.60 & 306.60 & Severe \\
Tower DC & 1.50 & 4.50 & 6.75 & 141.75 & Severe \\
Tower DC & 1.50 & 5.50 & 8.25 & 173.25 & Severe \\
Tower DC & 1.50 & 6.80 & 10.20 & 214.20 & Severe \\
Tower $\mathrm{AC}_{1}$ & 1.50 & 7.85 & 11.77 & 247.17 & Severe \\
Tower $\mathrm{AC}_{3}$ & 1.50 & 6.75 & 10.12 & 161.92 & Severe \\
Furnace $\mathrm{F}_{3}$ & 1.50 & 5.50 & 8.25 & 173.25 & Severe \\
Reservoir $\mathrm{ST}_{1}$ & 1.50 & 5.00 & 7.50 & 120.00 & High/heavy \\
Reservoir $\mathrm{ST}_{2}$ & 1.50 & 4.20 & 6.30 & & High/heavy \\
\hline
\end{tabular}


Table 9: Results of risk analysis for the processing units

\begin{tabular}{|c|c|c|c|c|c|c|c|c|c|c|}
\hline \multirow{2}{*}{ 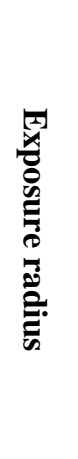 } & \multirow{2}{*}{$\begin{array}{l}B \\
0 \\
0 \\
0 \\
0 \\
0 \\
0 \\
0 \\
0 \\
0 \\
0 \\
0 \\
0\end{array}$} & \multirow{2}{*}{ 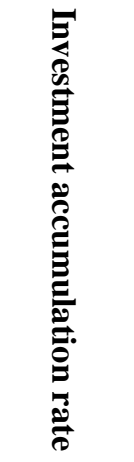 } & \multicolumn{2}{|c|}{ 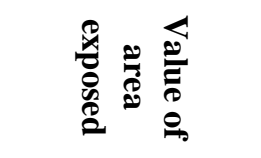 } & \multirow{2}{*}{ 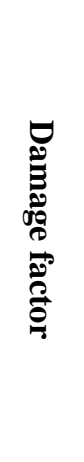 } & \multirow{2}{*}{ 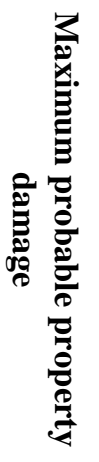 } & \multirow{2}{*}{ 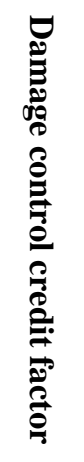 } & \multirow{2}{*}{ 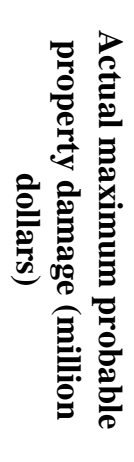 } & \multirow{2}{*}{ 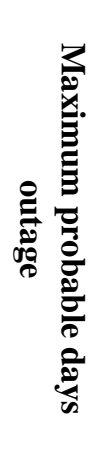 } & \multirow{2}{*}{ 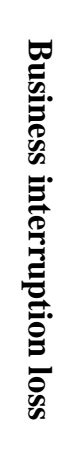 } \\
\hline & & & 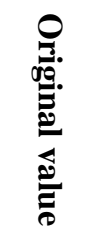 & 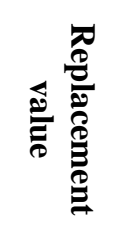 & & & & & & \\
\hline 79 & 19597 & 0.00130 & 25.47 & 24.01 & 0.83 & 19.92 & 0.58 & 11.55 & 49 & 114 \\
\hline 65 & 13266.5 & 0.00100 & 13.26 & 12.50 & 0.83 & 10.37 & 0.60 & 6.22 & 34 & 79 \\
\hline 63 & 12463 & 0.00141 & 17.57 & 16.56 & 0.83 & 13.74 & 0.62 & 8.51 & 41 & 96 \\
\hline 55 & 9498.5 & 0.00128 & 12.15 & 11.45 & 0.83 & 9.50 & 0.54 & 5.13 & 30 & 70 \\
\hline 45 & 6358.5 & 0.00125 & 7.94 & 7.48 & 0.83 & 6.30 & 0.62 & 3.84 & 25 & 58 \\
\hline 44.5 & 6218 & 0.00135 & 8.39 & 7.91 & 0.83 & 6.56 & 0.61 & 4.00 & 26 & 61 \\
\hline 44.5 & 6218 & 0.00129 & 8.02 & 7.56 & 0.83 & 6.27 & 0.63 & 3.95 & 25 & 58 \\
\hline 41 & 5278 & 0.00135 & 7.28 & 8.86 & 0.68 & 4.66 & 0.48 & 2.23 & 18 & 42 \\
\hline 36 & 4069 & 0.00140 & 5.69 & 5.36 & 0.83 & 4.44 & 0.49 & 2.17 & 18 & 50 \\
\hline 34 & 3630 & 0.00126 & 4.57 & 4.30 & 0.77 & 3.31 & 0.59 & 1.95 & 17 & 40 \\
\hline 31 & 3018 & 0.00138 & 4.16 & 3.92 & 0.65 & 2.54 & 0.51 & 1.29 & 13 & 30 \\
\hline
\end{tabular}

The risk of fire and explosion in processing units was investigated through the use of the calculated fire and explosion index (Table 9). Based on the results, the actual MPPDs for Reactor R-C and Reservoir $\mathrm{ST}_{1}$ were the highest (11.55) and lowest (1.29), respectively. The MPDO was determined for Reactor R-C (49 days). As can be observed in table 9, Furnace $\mathrm{F}_{3}$ and Tower $\mathrm{AC}_{3}$ had the maximum (0.63) and minimum (0.48) damage control credit factor, respectively. The Actual maximum and minimum probable property were, respectively, obtained for Reactor R-C (11.55 million dollars) and Reservoir $\mathrm{ST}_{1}$ (1.29 million dollars). Tower $\mathrm{AC}_{1}$ and Reactor $\mathrm{R}-\mathrm{B}$ were at the next levels with actual MPPDs of equal to 8.51 and 6.22 million dollars, respectively. Moreover, maximum and minimum BI loss was obtained for Reactor R$\mathrm{C}$ (114) and Reservoir $\mathrm{ST}_{1}$ (30), respectively. Maximum and minimum VAE was obtained for Reactor R-C (25.47) and Reservoir $\mathrm{ST}_{1}$ (4.16), respectively. The maximum and minimum investment accumulation rates
(OCD) were obtained for Tower $\mathrm{AC}_{1}$ (0.00141) and Reactor R-B (0.00100), respectively. The maximum and minimum AOEs were that of Reactor R-C (19597) and Reservoir $\mathrm{ST}_{1} \quad$ (3018), respectively. Furthermore, the maximum and minimum values of ERs were obtained for Reactor R-C (79) and Reservoir $\mathrm{ST}_{2}$ (34), respectively.

\section{Discussion}

The results of the present study indicated that Reactor R-C had the maximum F\&EI. In addition, damage to property and production cessation days of Reactor R-B and Tower $\mathrm{AC}_{1}$ were at the second and third levels, respectively. The $\mathrm{F}_{3}$ of Reactor R-C was equal to 14.6 which was higher than the other units. Moreover, the $\mathrm{F}_{1}$ of this unit was 6.95 which was the highest value after Tower $\mathrm{AC}_{1}\left(\mathrm{~F}_{1}=\right.$ 7.85). It was concluded that $F_{3}$ and $F_{1}$ can be important parameters in determining the risks of fire and explosion hazards level. This conclusion is in accordance with the results of researches conducted by Etowa et al. (5) and 
Suardin et al. (7) who have concluded that material usage reduction results in lower F\&EI.

The obtained indices for the studied processing units were higher than the fire and explosion index of the isocyanate storage reservoir at Bupal event (F\&EI was equal to 238) which caused about 2000 deaths and poisoning of 10000 individuals (13). This indicates the critical conditions of the mentioned processing units. However, the calculated value was less than the fire and explosion index obtained by Nezameddini et al. at an oil extraction company which was equal to 243.68 (15). The same index was obtained as 161 in the research conducted by Gupta et al. on an ammoniac synthesis reactor (12).

The other processing units were ranked according to their criticality (from high to low) as Tower $\mathrm{DC}_{3}$, Reactor R-A, Tower $\mathrm{DC}_{2}$, Furnace $\mathrm{F}_{3}$, Tower $\mathrm{AC}_{3}$, Tower $\mathrm{DC}_{1}$, Reservoir $\mathrm{ST}_{2}$, and Reservoirs $\mathrm{ST}_{1}$.

The results of the study indicated that the fire and explosion hazards level were severe at $82 \%$ of the studied processing units and heavy/high at the rest of units. This reveals the high level of fire and explosion hazards at the studied company. In the research conducted by Jafari et al. (16), the fire and explosion hazards level was determined as severe for $75 \%$ of the refinery Isomax unit. Results of the present study indicated that Reactor R-C had the maximum ER of $79 \mathrm{~m}$, while ER was calculated as $41 \mathrm{~m}$ in the research conducted by Gupta et al. (12).

Furthermore, the costs of probable accidents were calculated as 51 million dollars with the induced 296 days of production cessation. The maximum cost of probable accidents was obtained for Reactor R-C as 11.55 million dollars while the same parameter was calculated as 21 million dollars in the research conducted by Gupta et al. on an ammoniac synthesis reactor (12). The estimated value represents the huge economic losses due to the occurrence of such accidents. The obtained value is the most realistic loss which is calculated by considering the existing safety and protective operations and equipment.

In some studies, the F\&EI is successfully used as a tool to evaluate the inherent safety of the chemical process and it can provide a more understandable view of the process risks. In order to reduce the F\&EI in the studied processing units, reduction of existing hazardous materials and processes operation pressure can be useful. The results of the study by Etowa et al. showed that when the operating pressure and the existing materials are reduced, F\&EI is reduced in accordance with the principles of inherent immunity. However, changes in the amount of material in the processes had greater effect on the F\&EI compared with pressure changes (6).

F\&EI is an important tool for the determination of the risk of industrial processes and over time its weaknesses have been eliminated. For example, Gupta et al. stated in their study that the current methods of F\&EI calculation not consider control measures effect on the F\&EI value Therefore this makes the industry consider more dangerous. They suggested that the effects of lack of control measures should be included in F\&EI calculation (12). In addition, Suardin et al. suggested that F\&EI can be used as a measure in the optimization of design by integrating the F\&EI in design optimization (5).

\section{Conclusion}

Results of the present case study emphasized the existence of several weakness points at the selected unit by determining the fire and explosion hazards of its processing units. According to the identified hazards and parameters effective on their occurrence, it was concluded that the control and reduction of process hazards require incorporation of comprehensive engineering controls. Hence, Dow's index may be incorporated as an efficient tool by process design engineers in achieving safe and low-hazard chemical processes. Thus, the utilization of this index is 
suggested at all stages of a chemical company's life cycle for the prevention of fire and explosion accidents occurrence.

\section{Acknowledgments}

The authors are grateful to all managers and staff of the studied processing company for their cooperation in this project.

Conflict of Interest: None declared

\section{References}

1. Less F. Lees' loss prevention in the process industries: Hazard identification, assessment and control. 4th ed. United Kingdom: ButterworthHeinemann; 2012.

2. American Instiute of Chemical Engineers (AIChE). Dow's fire \& explosion index hazard classification guide. $7^{\text {th }}$ ed. New York: The American Instiute of Chemical Engineers; 1994.

3. Gupta JP. Application of DOW's fire and explosion index hazard classification guide to process plants in the developing countries. J Loss Prev Process Ind 1997; 10(1):7-15.

4. Jensen N, Jorgensen SB. Taking credit for loss control measures in the plant with the likely loss fire and explosion index (LL-F\&EI). Process Saf Environ Prot 2007; 85(B1):51-8.

5. Suardin JA, Mannan S, El-Halwagi MM. The integration of Dow's fire and explosion index (F\&EI) into process design and optimization to achieve inherently safer design. J Loss Prev Process Ind 2007; 20(1):79-90.

6. Etowa CB, Amyotte PR, Pegg MJ, Khan FI. Quantification of inherent safety aspects of the Dow indices. J Loss Prev Process Ind 2002; 15(6):477-87.

7. Rigas F, Konstandinidou M, Centola P, Reggio GT. Safety analysis and risk assessment in a new pesticide production line. J Loss Prev Process Ind 2003; 16(2):103-9.

8. Hendershot DC. Safety through design in the chemical process industry: inherently safer process design. Philadelphia, Pennsylvania: The Institute for Safely Through Design, National Safety Council, Rohm and Haas Company; 1999 July $17.16 \mathrm{p}$.

9. Ahmadi S, Adl J, Ghalenoei M. Rational ranking of fire and explosion in a petrochemical industry by fire and explosion index. The Journal of Qazvin University of Medical Sciences 2011; 14(4):50-6.

10. Ahmadi S, Adl J, Varmazyar S. Risk quantitative determination of fire and explosion in a process unit by DOW's fire and explosion index. Iran Occupational Health Journal 2008; 5(1-2):39-46.

11. American National Standards Institute. NFPA 325: Guide to fire hazard properties of flammable liquids, gases, and volatile solids. $1^{\text {st }}$ ed. United States of America: National Fire Protection Association; 1994.

12. Gupta JP, Khemani G, Mannan MS. Calculation of Fire and Explosion Index (F\&EI) value for the Dow Guide taking credit for the loss control measures. J Loss Prev Process Ind 2003; 16(4):235-41.

13. Khan FI, Sadiq R, Amyotte PR. Evaluation of available indices for inherently safer design options. Process Safety Progress 2003; 22(2):8397.

14. Suardin JA. The integration of dow's fire and explosion index into process design and optimization to achieve an inherently safer design [MSc Thesis]. College Station, Texas: Texas A\&M University; 2005.

15. Nezamodini ZS, Rezvani Z, Kian K. Fire and explosion risk assessment in a process unit using dow's fire and explosion index. Journal of Health and Safety at Work 2015; 4(4):29-38.

16. Jafari MJ, Zarei M, Movahhedi M. The credit of fire and explosion index for risk assessment of iso-max unit in an oil refinery. International Journal of Occupational Hygiene 2012; 4(1):106. 